Tersedia online di: http://ejournal-balitbang.kkp.go.id/index.php/jra

\title{
PENGARUH KEPADATAN TERHADAP SINTASAN, PERTUMBUHAN, DAN GAMBARAN DARAH BENIH IKAN BETUTU Oxyeleotris marmorata
}

\author{
Tri Heru Prihadi\#, Adang Saputra, Gleni Hasan Huwoyon, dan Brata Pantjara \\ Balai Riset Perikanan Budidaya Air Tawar dan Penyuluhan Perikanan \\ (Naskah diterima: 13 Desember 2017; Revisi final: 27 Desember 2017; Disetujui publikasi: 27 Desember 2017)
}

\begin{abstract}
ABSTRAK
Ikan betutu Oxyeleotris marmorata merupakan ikan lokal potensial menjadi komoditas budidaya. Performa pertumbuhan dan sintasan dapat ditingkatkan dengan mengoptimalkan padat tebar. Tujuan penelitian adalah menentukan padat tebar yang menghasilkan sintasan dan pertumbuhan tinggi, serta respons fisiologis terbaik. Kolam yang digunakan berukuran $2 \mathrm{~m} \times 1 \mathrm{~m} \times 1 \mathrm{~m}$ dan diisi air $1 \mathrm{~m}^{3}$. Perlakuan yang diuji adalah kepadatan $50 \mathrm{ekor} / \mathrm{m}^{3}, 100 \mathrm{ekor} / \mathrm{m}^{3}$, dan $150 \mathrm{ekor} / \mathrm{m}^{3}$. Ukuran benih yang digunakan 4,24 $\pm 0,58$ $\mathrm{cm}$ dengan bobot $2,74 \pm 0,45 \mathrm{~g}$. Selama 60 hari masa pemeliharaan, pakan yang diberikan adalah cacing sutra Tubifex sp. secara sekenyangnya. Hasil penelitian menunjukkan sintasan benih ikan betutu yang dipelihara pada berbagai padat tebar tidak berbeda secara nyata, pertumbuhan spesifik panjang $(1,50 \pm$ $0,37 \%$ hari) dan bobot total benih ikan betutu $(1,95 \pm 0,32 \%$ hari) tertinggi, dan perubah respons fisiologis berupa gambaran darah paling stabil dicapai pada padat tebar $50 \mathrm{ekor} / \mathrm{m}^{3}$, serta biomassa tertinggi dicapai pada kepadatan $150 / \mathrm{m}^{3}$. Hasil penelitian ini dapat dijadikan informasi dasar untuk melakukan pendederan ikan betutu secara terkontrol.
\end{abstract}

\section{KATA KUNCl: kepadatan; sintasan; pertumbuhan; ikan betutu; Oxyleotris marmorata}

ABSTRACT: The effect of stocking density on survival rate, growth, and hematological parameters of sand goby Oxyeleotris marmorata Juvenile. By: Tri Heru Prihadi, Adang Saputra, Gleni Hasan Huwoyon, and Brata Pantjara

Sand goby, Oxyeleotris marmorata is a potential fish species for aquaculture in Indonesia. However, the growth performance and survival rate of the fish seed are still low. Such challenges could be solved through the optimization of stocking density of the fish. The research objective was to determine the optimal stocking density to produce high growth and survival rate, as well as the best physiological response. The ponds used in this experiment were $2 \mathrm{~m} \times 1 \mathrm{~m}$ $\mathrm{x} 1 \mathrm{~m}$ in size (water volume: $1 \mathrm{~m}^{3}$ ). The stocking density treatments were 50,100 , and 150 individual $/ \mathrm{m} 3$. The initial fish length average was $4.24 \pm 0.58 \mathrm{~cm}$, with the initial body weight average of $2.74 \pm 0.45 \mathrm{~g}$. During 60 days of rearing period, the fish were fed with Tubifex sp. ad libitum. The results showed that the survival rates on different stocking densities were not significantly different. The highest specific growth on length $(1.50 \pm 0.37 \%$ day) and body weight total $(1.95 \pm 0.32 \%$ day) and the most stable physiological response related to its hematological parameters were achieved by seed stocked at 50 individuals/m3. The best biomass total was achieved by seed stocked at 150 individuals $/ \mathrm{m} 3$. The result of this study could be applied as basic information to culture sand goby in a controlled environment.

\section{KEYWORDS: stocking density; survival rate; growth; sand goby, Oxyeleotris marmorata}

\section{PENDAHULUAN}

Ikan betutu Oxyeleotris marmorata merupakan ikan lokal potensial menjadi komoditas budidaya (Sukadi et al., 2009). Kegiatan budidaya ikan betutu sudah berkembang mulai dari tahap pedederan sampai

\footnotetext{
\# Korespondensi: Balai Riset Perikanan Budidaya Air Tawar dan Penyuluhan Perikanan. Jl. Sempur No. 1, Bogor 16154, Indonesia. Tel. + 622518313200

E-mail: triheru_p@yahoo.com
}

pembesaran. Penelitian terkait ikan betutu di antaranya pakan alami dan pakan buatan (Arief et al., 2009), dan salinitas optimum (Ardi et al., 2016). Namun pada tahap ini, kinerja petumbuhan dan sintasan masih rendah.

Upaya peningkatan performa pertumbuhan benih ikan betutu sudah dilakukan, namun hasilnya masih belum optimum (Darwis et al., 2009). Tingkat kematian masih tinggi, dengan gejala klinis tidak mau makan, badan kurus dan lemas. Menurut Ismail (2010), 
ikan betutu sangat sensitif terhadap perubahan yang terjadi, baik bersifat eksternal maupun internal. Namun demikian, ikan mempunyai kemampuan homeostasis tubuh sangat cepat untuk merespons segala bentuk perubahan sehingga tetap bisa tumbuh dan berkembang dengan normal.

Benih ikan betutu seperti hal nya ikan-ikan air tawar lainnya berusaha untuk mencapai kondisi homeostasi antara sistem internal (tubuh) dengan sistem eksternal (air/media pemeliharaan). Proses homeostasi ionik terkait dengan ion $\mathrm{Na}^{+}$pada ikan, juga melibatkan regulasi hormonal (endokrin) di antaranya kortisol (Cruz et al., 2013). Selanjutnya kortisol akan merangsang perubahan glikogen menjadi glukosa untuk menyediakan energi dalam proses transpor aktif. Selain itu, kortisol juga memiliki peran meningkatkan penyerapan $\mathrm{Na}^{+}$melalui reseptor glukokortikoid melalui metabolon fungsional $\mathrm{NHE}_{3} \mathrm{~b}$ Rhcg 1 (Kumai et al., 2012). Hal ini disebabkan peningkatan produksi kortisol untuk merubah glikogen menjadi glukosa darah sebagai salah satu bentuk energi dalam menunjang proses homeostasis.

Peningkatan produktivitas benih ikan betutu salah satunya dengan mengoptimalkan padat tebar. Menurut Subagja \& Radona (2017), pada tahap pendederan diperlukan penentuan padat tebar agar sintasan dan pertumbuhan tetap optimal. Hal ini sesuai dengan pendapat Wedemeyer (2001), padat tebar diambang batas tertentu, akan mengganggu proses fisiologis, sehingga dapat menurunkan sintasan dan pertumbuhan. Beberapa penelitian terkait padat terbar ikan-ikan air tawar prospektif yang sudah dilakukan di antaranya, pascalarva ikan nilem Osteochilus vittatus (Radona et al., 2012); ikan tambakan Helostoma temminckii (Joko et al., 2013); ikan uceng Nemacheilus fasciatus (Prakoso et al., 2016); ikan Ialawak Barbonymus balleroides (Kusmini et al., 2017); dan ikan semah Tor douronensis (Valenciennes, 1842) (Subagja \& Radona, 2017).

Informasi terkait padat tebar terhadap peningkatan kinerja sintasan, pertumbuhan, dan respons stres benih ikan betutu sampai saat ini masih terbatas. Tujuan penelitian ini adalah menentukan padat tebar yang menghasilkan sintasan dan pertumbuhan tinggi, serta respons fisiologis terbaik.

\section{BAHAN DAN METODE}

Penelitian telah dilaksanakan di kolam milik pembudidaya ikan di Dusun Binong Poncol, RT 01/ RW 06, Desa Babakan Kecamatan Ciseeng Kabupaten Bogor Provinsi Jawa Barat. Penelitian ini dirancang dengan rancangan acak lengkap. Perlakuan yang diberikan berupa padat tebar 50, 100, dan 150 ekor/ $\mathrm{m}^{3}$, masing-masing tiga ulangan.

Kolam yang digunakan berupa kolam beton pada bagian dinding dengan dasar berupa tanah dan seluruh kolam dilapisi dengan terpal. Ukuran kolam $2 \mathrm{~m} \times 1 \mathrm{~m}$ $\mathrm{x} 1 \mathrm{~m}$ yang diisi air $1 \mathrm{~m}^{3}$. Air yang digunakan bersumber dari air sungai, sebelum digunakan air ditampung dulu pada wadah penampungan untuk mengendapkan partikel-partikel terlarut. Pengisian air setinggi 0,5 $\mathrm{cm}$ dan dibiarkan sekitar 4-5 hari sebelum ditebar benih ikan betutu. Pergantian air sebanyak 20\%30\% dilakukan setiap dua hari sekali.

Benih ikan betutu yang digunakan berasal dari satu induk hasil dari pengumpul di Desa Ciseeng. Ukuran benih yang digunakan 4,24 $\pm 0,58 \mathrm{~cm}$ dengan bobot $2,74 \pm 0,45 \mathrm{~g}$. Benih disebar secara acak pada sembilan kolam sesuai perlakuan. Penebaran benih ikan betutu dilakukan so re hari. Selama 60 hari masa pemeliharaan, pakan yang diberikan adalah cacing sutra Tubifex sp. sekenyangnya. Hasil proksimat cacing sutra (persentase bobot kering) sebagai berikut: protein $57,10 \%$ lemak $15,95 \%$ kadar abu 5,32\% serat kasar 1,94\% dan BETN 19,69\%(Priyadi et al., 2010).

Sintasan dihitung pada akhir pemeliharaan. Pertumbuhan panjang, bobot, dan laju pertumbuhan harian dihitung setiap 15 hari. Panjang badan diukur dengan pengaris dengan jumlah sampel sebanyak 15 ekor/kolam, bobot badan menggunakan timbangan dengan ketelitian dua desimal. Parameter sintasan, pertumbuhan panjang mutlak, laju pertumbuhan harian, biomassa dihitung berdasarkan rumus menurut Effendie (2002). Analisis gambaran darah terdiri atas glukosa darah, total leukosit, total eritrosit, hematokrit, dan hemoglobin mengacu pada metode Blaxhall \& Daisley (1973).

Parameter kualitas air sebagai data pendukung diukur setiap 15 hari. Parameter kualitas air yang diukur terdiri atas suhu air menggunakan termometer air raksa, pH menggunakan $\mathrm{pH}$ meter merek Horiba dengan ketelitian dua desimal, oksigen terlarut menggunakan DO meter merek Horiba dengan ketelitan dua desimal. Nitrit mengacu pada SNI 066989.9-2005, dan amonia mengacu pada SNI 066989.30-2005.

Data yang diperoleh kemudian ditabulasi, sintasan dan pertumbuhan dihitung pada akhir penelitian dan dianalisis dengan ANOVA pada sel ang kepercayaan 95\% Apabila terjadi perbedaan yang nyata, dilakukan uji lanjut Duncan menggunakan program SPSS versi 18. Parameter kualitas air dianalisis secara deskriptif. 


\section{HASIL DAN BAHASAN}

Sintasan benih ikan betutu yang dipelihara pada berbagai padat tebar selama 60 hari masa pemeliharaan disajikan pada Gambar 1. Hasil perhitungan menunjukkan padat penebaran tidak berpengaruh nyata terhadap sintasan $(P>0,05)$. Kondisi ini menggambarkan padat tebar tidak memberikan pengaruh terhadap sintasan, karena pada kondisi ini benih ikan betutu masih dapat tumbuh dan berkembang dengan normal. Hal ini diduga padat tebar yang diberikan masih dalam kondisi optimum, sehingga tidak ada persaingan mendapatkan ruang yang mengakibatkan ikan menjadi stres. Hal ini tercermin dari kadar glukosa darah yang terukur menunjukkan pola yang stabil pada setiap perlakuan, kecuali pada padat teber $150 / \mathrm{m}^{3}$ ada sedikit perubahan pada pengamatan hari ke-15 dan selanjutnya kembali stabil sampai akhir pemeliharaan (Gambar 4). Kondisi ini sesuai dengan pendapat Cotas et al. (2008), rendahnya glukosa darah menandakan tidak terjadi mobilisasi glukosa ke dalam darah sebagai sumber energi untuk pertumbuhan.

Perlakuan padat tebar memberikan pengaruh nyata terhadap pertumbuhan benih ikan betutu. Laju pertumbuhan panjang mutlak individu benih ikan betutu berbeda nyata di antara ketiga perlakuan. Padat tebar 50 ekor $/ \mathrm{m}^{3}$ menghasilkan pertumbuhan panjang mutlak tertinggi dengan nilai $6,29 \pm 1,67 \mathrm{~cm}$ (Gambar 2). Pertumbahan mutlak benih ikan betutu yang dipelihara selama 60 hari berbeda nyata antar perlakuan $(\mathrm{P}<0,05$; Gambar 2).

Berdasarkan hasil perhitungan selama proses penelitian, pertumbuhan terbaik dicapai dengan kepadatan $50 \mathrm{ekor} / \mathrm{m}^{3}$. Hal ini diduga benih ikan betutu mampu memanfaatkan ruang dan mengoptimalkan makanan yang tersedia tanpa harus mengeluarkan energi yang besar. Hal ini sesuai dengan penelitian yang dilakukan pada ikan semah (Subagja \& Radona, 2017); ikan uceng (Prakoso et al., 2016); dan benih ikan gabus (Wahyu et al., 2015); senegalese solea Solea senegalensis (Cotas et al., 2008).

Padat penebaran pada pendederan ikan betutu berpengaruh nyata terhadap laju pertumbuhan spesifik baik panjang maupun bobot. Semakin tinggi padat tebar, laju pertumbuhan semakin rendah. Laju pertumbuhan spesifik panjang mutlak dan bobot total disajikan pada Gambar 3.

Padat tebar merupakan faktor yang menjadi pertimbangan prioritas dalam budidaya ikan. Optimalisasi padat penebaran akan memengaruhi terhadap respons fisiologis ikan selama siklus hidupnya, sehingga ikan terhindar dari aktivitas sistem stres (Barton, 2002; Barreto \& Volpato, 2006; Iwama et al., 1999).

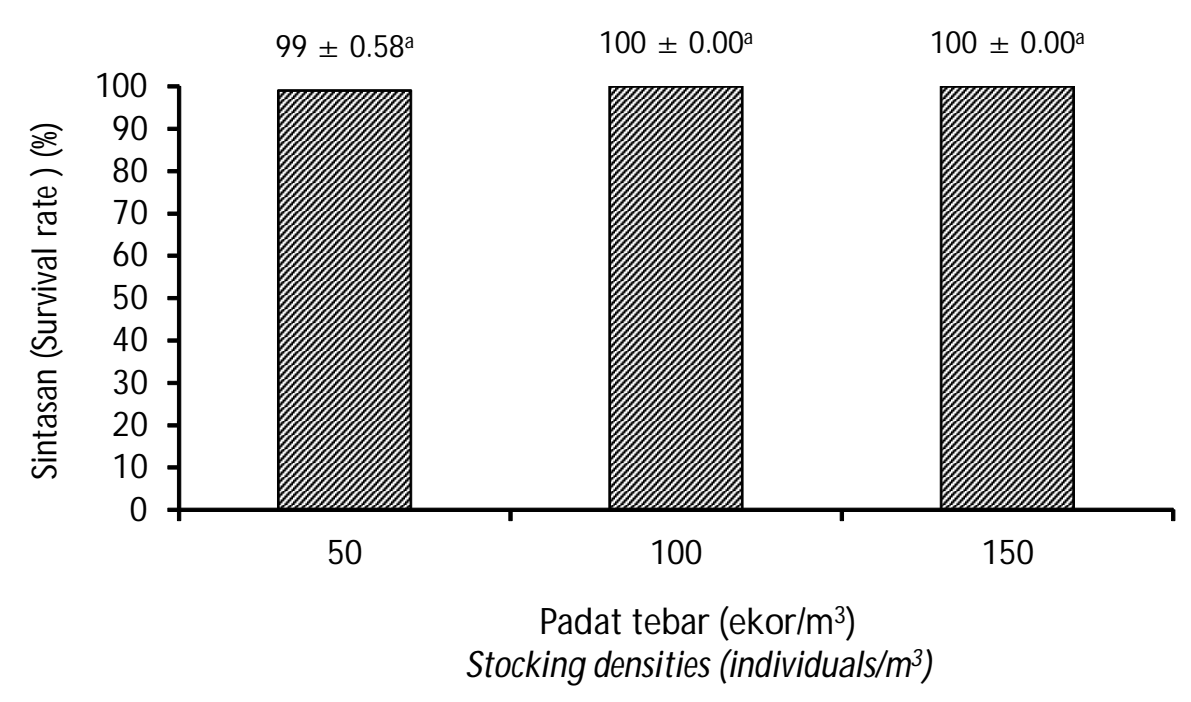

Keterangan: Angka yang diikuti huruf superskrip yang sama menunjukkan tidak adanya perbedaan yang nyata $(P>0,05)$

Remark: Numbers followed by the same superscript letter indicate no significant difference $(P>0.05)$

Gambar 1. Sintasan ikan betutu pada berbagai padat tebar selama 60 hari masa pemeliharaan.

Figure 1. Survival rate of sand goby during 60 days of rearing in various stocking densities. 

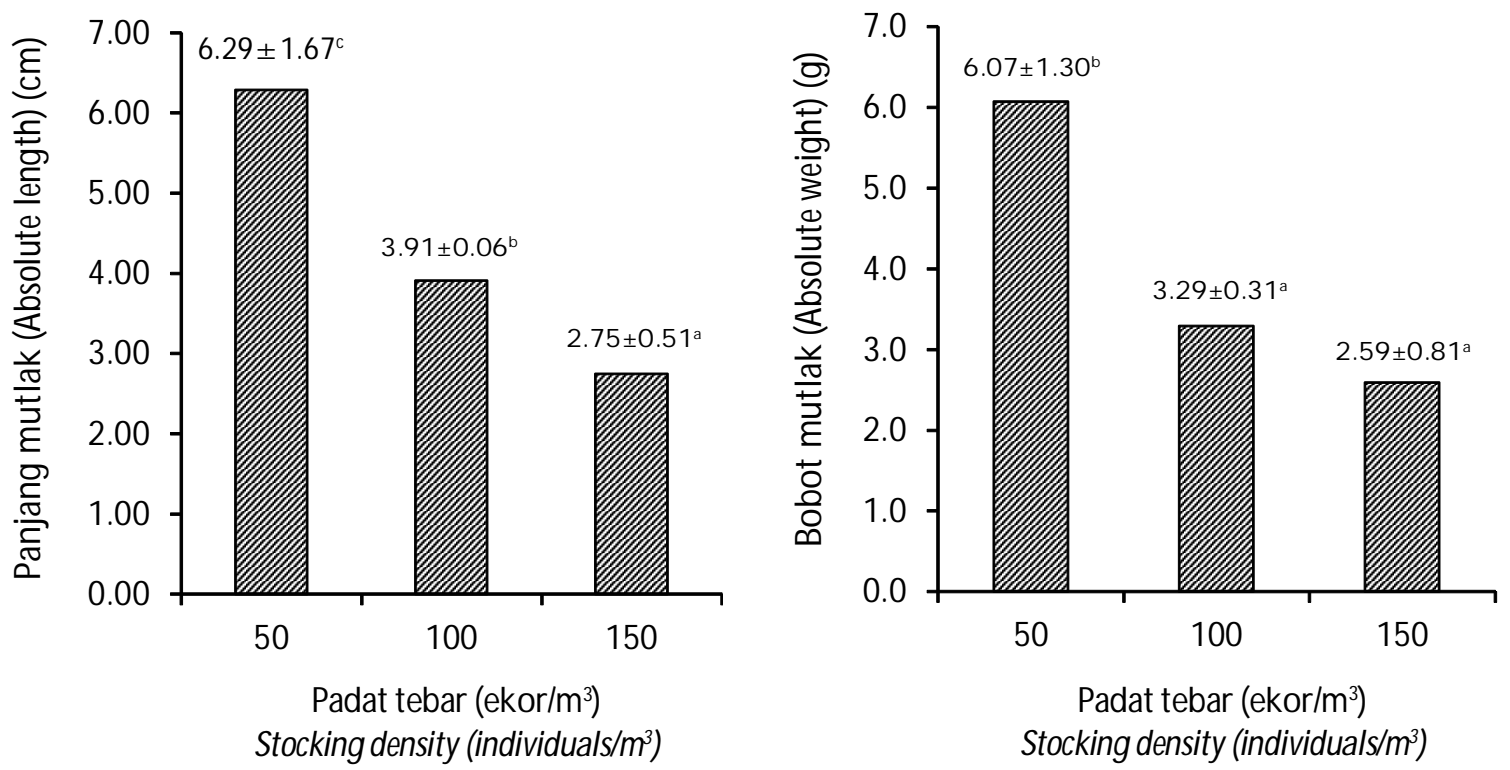

Keterangan: Angka yang di ikuti huruf superskrip yang sama menunjukkan tidak adanya perbedaan yang nyata $(P>0,05)$

Remarks: Numbers followed by the same superscript letter indicate no significant difference $(P>0.05)$

Gambar 2. Panjang dan bobot mutlak ikan betutu pada berbagai padat tebar selama 60 hari masa pemeliharaan.

Figure 2. Absolute length and body weight of sand goby reared for 60 days of rearing in various stocking densities.
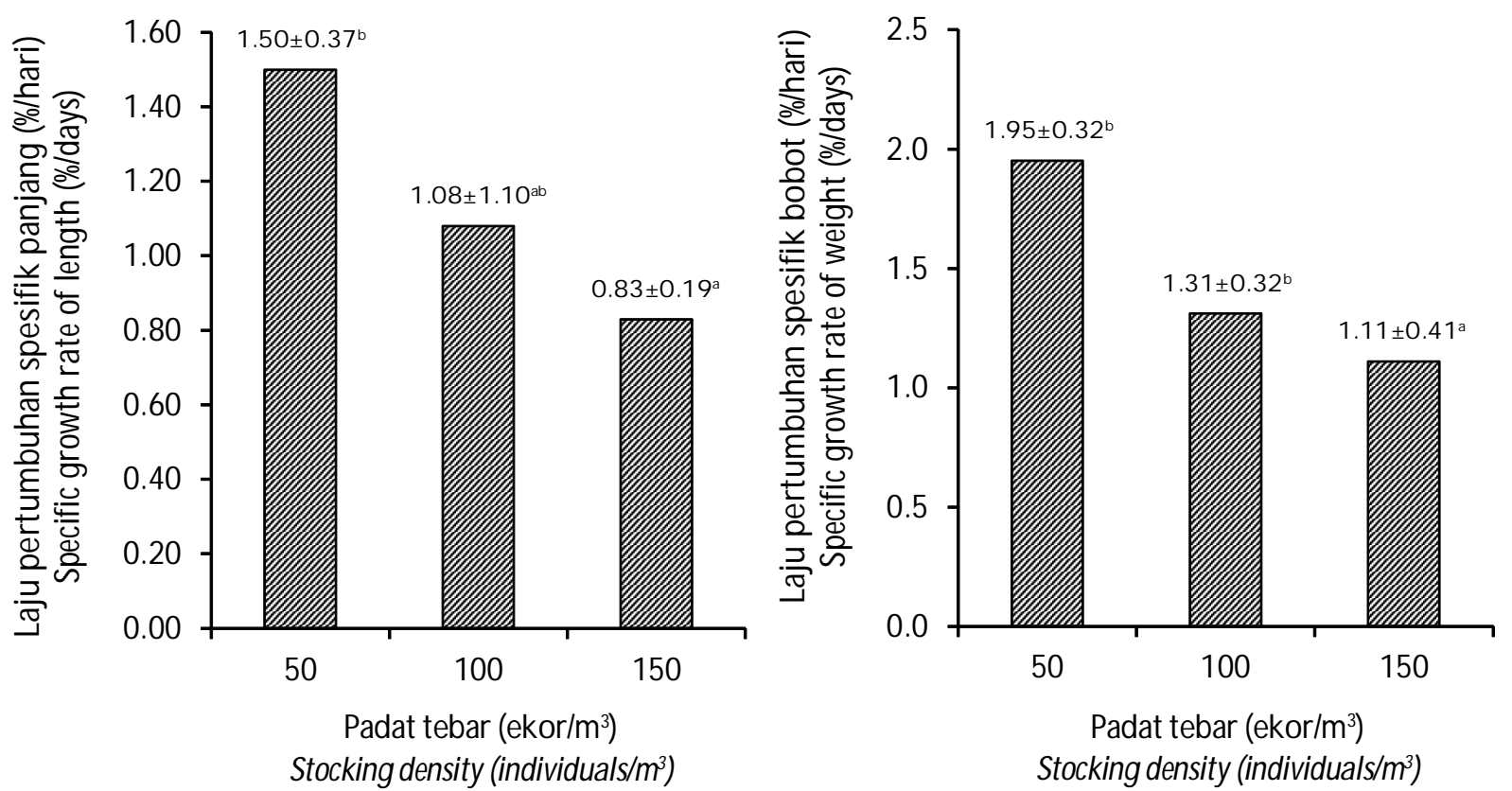

Keterangan: Angka yang diikuti huruf superskrip yang sama menunjukkan tidak adanya perbedaan yang nyata $(P>0,05)$ Remarks: $\quad$ Numbers followed by the same superscript letter indicate no significant difference $(P>0.05)$

Gambar 3. Laju pertumbuhan spesifik panjang dan bobot mutlak ikan betutu pada berbagai padat tebar selama 60 hari masa pemeliharaan.

Figure 3. Specific growth rate length and body weight of sand goby reared for 60 days in various stocking densities. 
Tabel 1. Biomassa ikan betutu yang dipelihara pada berbagai kepadatan selama 60 hari masa pemeliharaan

Table 1. Sand goby biomass reared for 60 days in various stocking densities

\begin{tabular}{cc}
\hline $\begin{array}{c}\text { Padat tebar } \\
\text { Stocking density }\end{array}$ & $\begin{array}{c}\text { Biomassa } \\
\text { Biomass }(\mathbf{m g})\end{array}$ \\
\hline $50 \mathrm{ekor} / \mathrm{m}^{3}$ (individuals $/ \mathrm{m}^{3}$ ) & $1,311.58 \pm 40.88^{\mathrm{a}}$ \\
$100 \mathrm{ekor} / \mathrm{m}^{3}$ (individuals $/ \mathrm{m}^{3}$ ) & $1,808.00 \pm 17.93^{\mathrm{b}}$ \\
$150 \mathrm{ekor} / \mathrm{m}^{3}$ (individuals $/ \mathrm{m}^{3}$ ) & $2,384.37 \pm 79.67^{\mathrm{c}}$ \\
\hline Keterangan: Angka yang diikuti huruf superskrip yang sama menunjukkan \\
tidak adanya perbedaan yang nyata (P>0,05) \\
Remarks: $\quad$ Numbers followed by the same superscript letter indicate no \\
& significant difference (P>0.05)
\end{tabular}

Biomassa ikan betutu yang dipelihara selama 60 hari pada berbagai kepadatan berbeda nyata $(P<0,05$; Tabel 1). Biomassa tertinggi dicapai pada kepadatan $150 \mathrm{ekor} / \mathrm{m}^{3}$, sedangkan terendah pada $50 \mathrm{ekor} / \mathrm{m}^{3}$. Namun demikian, bobot rata-rata ikan betutu antara kepadatan 50 ekor $/ \mathrm{m}^{3}$ dan 100 ekor $/ \mathrm{m}^{3}$ tidak berbeda nyata $(P>0,05)$, tertinggi dicapai pada kepadatan 50 ekor $/ \mathrm{m}^{3}$ dan berbeda nyata dengan kepadatan 150 ekor/ $\mathrm{m}^{3}(\mathrm{P}<0,05)$. Hasil ini menggambarkan kepadatan 50 ekor $/ \mathrm{m}^{3}$ merupakan padat tebar terbaik untuk pemeliharaan benih ikan betutu.

Tingginya biomassa pada kepadatan $150 \mathrm{ekor} / \mathrm{m}^{3}$ disebabkan sintasan yang tinggi dan kepadatan tertinggi dibandingkan perlakuan lainnya. Kepadatan 50 ekor/m $\mathrm{m}^{3}$ menghasilkan biomassa terendah dibandingkan perlakuan lainnya, hal ini diduga karena jumlah ikan betutu yang ditebar paling sedikit dibandingkan perlakuan lainnya. Namun, rata-rata bobot lebih tinggi dibandingkan perlakuan lainnya, hal ini berkaitan dengan persaingan mendapat makanan yang lebih kecil dibanding perlakuan lainnya. Dengan demikian, efisiensi dalam memanfaatkan pakan lebih tinggi dibanding perlakuan lainnya. Menurut Zonneveld et al. (1991), pengaruh kepadatan pada pertumbuhan sangat kecil, sementara biomass standing crop meningkat secara langsung dengan meningkatnya kepadatan.

Pada Tabel 2 memuat kisaran parameter kualitas air selama 60 hari masa pemeliharaan benih ikan betutu pada berbagai kepadatan. Suhu, pH, DO, nitrit, dan amoniak pada setiap perlakuan masih dalam kondisi yang optimum untuk pemeliharaan benih ikan betutu (Olivera et al., 2012; Mallya, 2017; Ardi et al., 2016). Kondisi parameter kualitas air terukur masih sangat mendukung untuk pertumbuhan dan perkembangan dengan baik, serta tidak berpotensi mengakibatkan stres pada ikan yang dipelihara.

Gambaran glukosa darah pada setiap perlakuan disajikan pada Gambar 4. Hasil pengamatan hari ke-

Tabel 2. Kisaran nilai kualitas air untuk benih ikan betutu selama penelitian

Table 2. The water quality ranges in the rearing ponds during the experiment

\begin{tabular}{|c|c|c|c|c|}
\hline \multirow{2}{*}{$\begin{array}{l}\text { Parameter } \\
\text { Parameters }\end{array}$} & \multicolumn{3}{|c|}{$\begin{array}{c}\text { Padat tebar (ekor } / \mathrm{m}^{3} \text { ) } \\
\text { Stocking densities (individuals } / \mathrm{m}^{3} \text { ) }\end{array}$} & \multirow{2}{*}{$\begin{array}{l}\text { Kisaran optimum } \\
\text { - Optimum range }\end{array}$} \\
\hline & 50 & 100 & 150 & \\
\hline Suhu (Temperature) $\left({ }^{\circ} \mathrm{C}\right)$ & $28.10-31.50$ & $28.00-30.60$ & $28.10-32.10$ & $26-32^{1)}$ \\
\hline $\mathrm{pH}$ & $6.00-7.30$ & $6.20-7.30$ & $6.20-6.60$ & $4.25-9.4^{1)}$ \\
\hline $\begin{array}{l}\text { Oksigen terlarut } \\
\text { Dissolved oxygen (mg/L) }\end{array}$ & $1.77-5.44$ & $1.77-6.50$ & $1.79-5.57$ & $>1.73^{2)}$ \\
\hline Nitrit (Nitrite) (mg/L) & $0.14-8.60$ & $0.17-8.30$ & $0.35-13.70$ & $10^{3)}$ \\
\hline Amonia (Ammonia) ) (mg/L) & $0.001-0.007$ & $0.002-0.021$ & $0.005-0.017$ & $\leq 0.02^{3)}$ \\
\hline
\end{tabular}




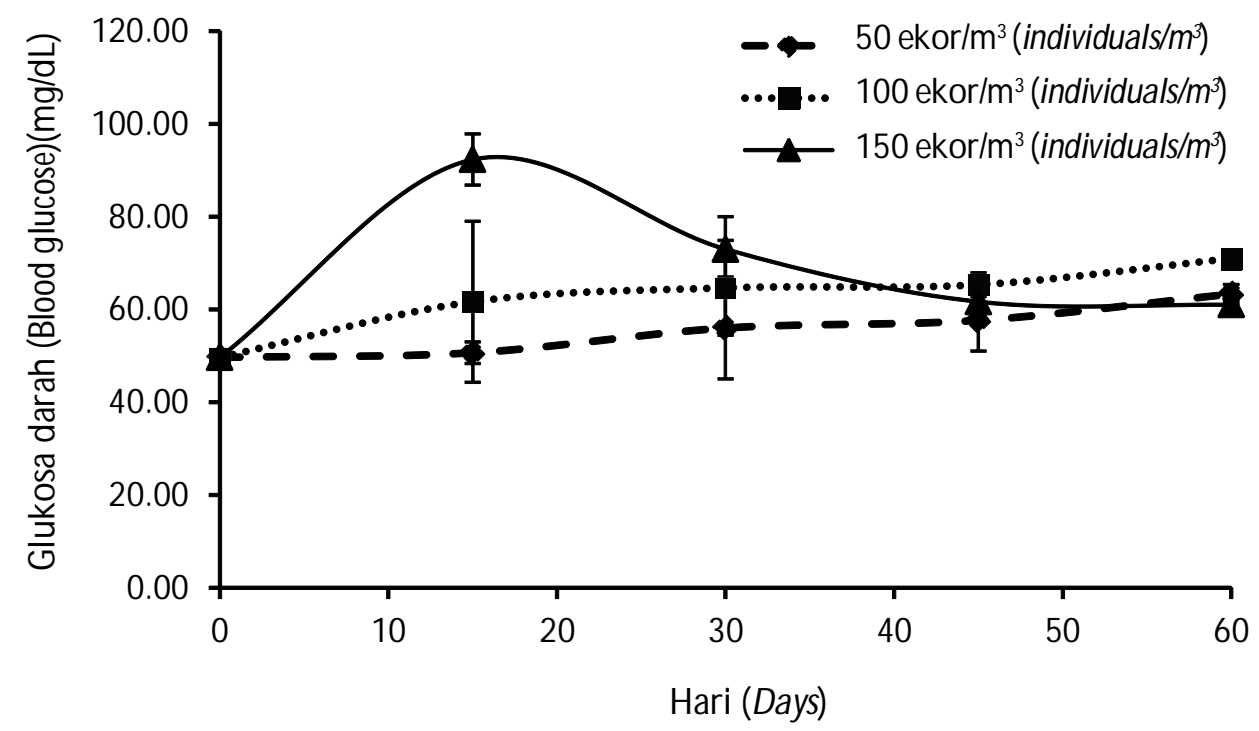

Gambar 4. Kadar glukosa darah ikan betutu pada berbagai padat tebar selama 60 hari masa pemeliharaan.

Figure 4. Blood glucose level of sand goby reared for 60 days in various stocking densities.

15, glukosa darah benih ikan betutu yang dipelihara pada kepadatan 150 ekor $/ \mathrm{m}^{3}$ mengalami perubahan yang relatif tinggi dibandingkan dengan padat tebar lainnya, kemudian relatif stabil kembali pada pengamatan hari ke-30 sampai akhir pemeliharaan. Hal ini menggambarkan setelah masa adaptasi, benih ikan betutu tidak terindikasi stres walapun dipelihara dengan padat tebar berbeda.

Pola sebaran total leukosit dan eritrosit benih ikan betuutu pada setiap pengamatan disajikan pada Gambar 5. Total leukosit benih ikan betutu sampai hari ke-30 mengalami peningkatan yang relatif tajam untuk semua perlakuan, kemudian menurun kembali sampai akhir penelitian. Total leukosit terkecil dicapai pada kepadatan 50 ekor $/ \mathrm{m}^{3}$ dan tertinggi 150 ekor/ $\mathrm{m}^{3}$. Total eritrosit menggambarkan pola yang sama dengan leukosit benih ikan betutu mulai hari pertama sampai hari ke-30 yaitu mengalami kenaikan yang relatif tajam untuk semua perlakuan, kemudian menurun kembali mulai hari ke-45 sampai akhir masa pemeliharaan. Kondisi ini menggambarkan benih ikan betutu pada berbagai kepadatan memerlukan waktu yang cukup lama untuk melakukan adaptasi terhadap kondisi fisiologi yang ada.

Pola sebaran hematokrit dan hemoglobin benih ikan betutu pada setiap pengamatan disajikan pada Gambar 6 . Pola sebaran hematokrit benih ikan betutu dari awal sampai akhir pemeliharaan tidak terjadi perubahan yang relatif tinggi, namun pada kepadatan
150 ekor/m³ mengalami kenaikan mulai hari ke-14 kemudian turun kembali mulai hari ke-45 sampai akhir pemeliharaan. Pola distribusi hemoglobin cenderung meningkat dari awal sampai akhir pemeliharaan untuk semua perlakuan (Gambar 6). Konsentrasi hemoglobin paling stabil dan terendah dicapai pada perlakuan 50 ekor/m³ dibandingkan perlakuan lainnya. Hal ini menggambarkan benih ikan betutu yang dipelihara pada padat tebar 50 ekor $/ \mathrm{m}^{3}$ kondisinya paling stabil dibandingkan padat tebar lainnya.

Tingginya kadar glukosa darah benih ikan betutu pada kepadatan 150 ekor $/ \mathrm{m}^{3}$ diduga dalam kondisi stres karena persaingan proses adaptasi. Kadar glukosa darah paling kecil dan stabil dicapai pada kepadatan $50 \mathrm{ekor} / \mathrm{m}^{3}$, hal ini mengambarkan tingkat stres yang rendah. Ikan yang mengalami stres mengakibatkan hiperglisemia, yang dapat mengganggu perkembangan selanjutnya bahkan dapat mematikan (Hastuti et al., 2003). Glukosa darah merupakan gambaran dari respons stres sebagai akibat dari pelepasan hormon kortisol di hipotalamus melalui aliran darah menuju hati untuk merombak glikogen menjadi glukosa, sehingga glukosa darah menjadi meningkat (Porchase et al., 2009).

Peningkatan total leukosit menunjukkan bahwa benih ikan betutu mengalami stres (Supriyono et al., 2011). Hal ini diduga berhubungan dengan respons imunitas yang dipengaruhi olah hormon kortikosteron saat ikan mengalami stres (Davis et al., 2008). Namun 

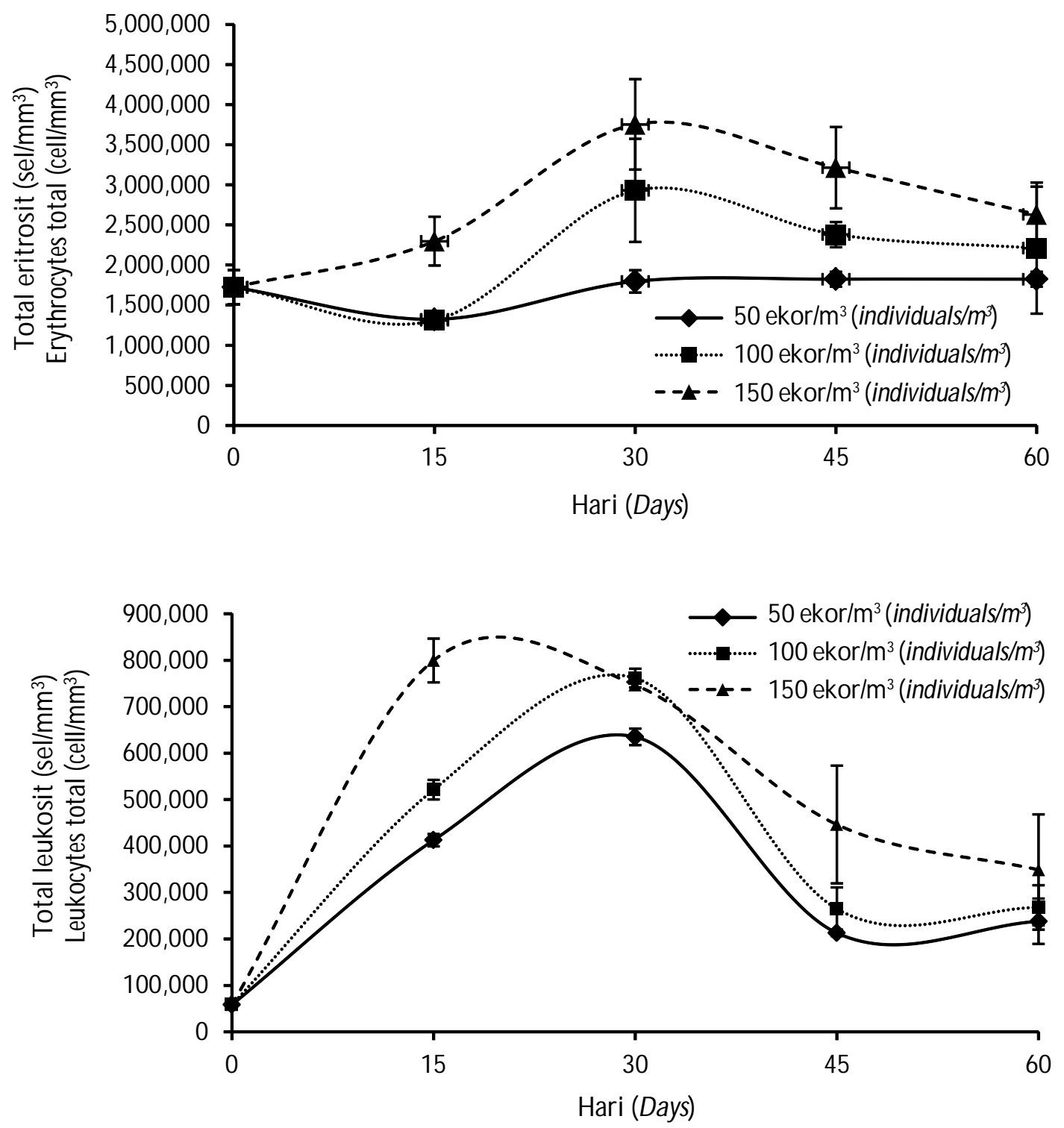

Gambar 5. Total leukosit dan eritrosit darah ikan betutu pada berbagai padat tebar selama 60 hari masa pemeliharaan.

Figure 5. Leukocytes and erythrocytes total of sand goby reared for 60 days in various stocking densities.

hasil penelitian menunjukkan padat tebar tidak memberikan pengaruh yang nyata terhaap sintasan. Kondisi ini menggambarkan perbedaan leukosit pada berbagai perlakuan masih dalam kondisi yang masih ditolelir ikan betutu untuk tumbuh dan berkembang dengan normal. Kondisi ini mendukung tingkat imunitas dalam mempertahankan diri dari patogen yang mematikan (Blaxhall, 1972).

Hemoglobin merupakan metaloprotein di dalam sel darah merah yang berfungsi sebagai pengangkut oksigen dari paru-paru ke seluruh tubuh. Hemoglobin juga pengusung karbon dioksida kembali menuju paru-paru untuk dihembuskan keluar tubuh (Wedemeyer, 1996). Hematokrit merupakan indikator terinfeksinya benih ikan betutu karena penyakit yang mengganggu sel darah merah, baik berlebihan ataupun kekurangan (Supriyono et al., 2011; Witeska, 2005). Hasil analisis terhadap hemoglobin dan hematokrit tidak terlihat ada perubahan yang ekstrem pada berbagai kepadatan, namun paling stabil diperoleh pada kepadata 50 ekor $/ \mathrm{m}^{3}$.

Hasil analisis terhadap parameter uji menunjukkan padat tebar tidak memberikan pengaruh yang nyata terhadap sintasan benih ikan betutu, namun 

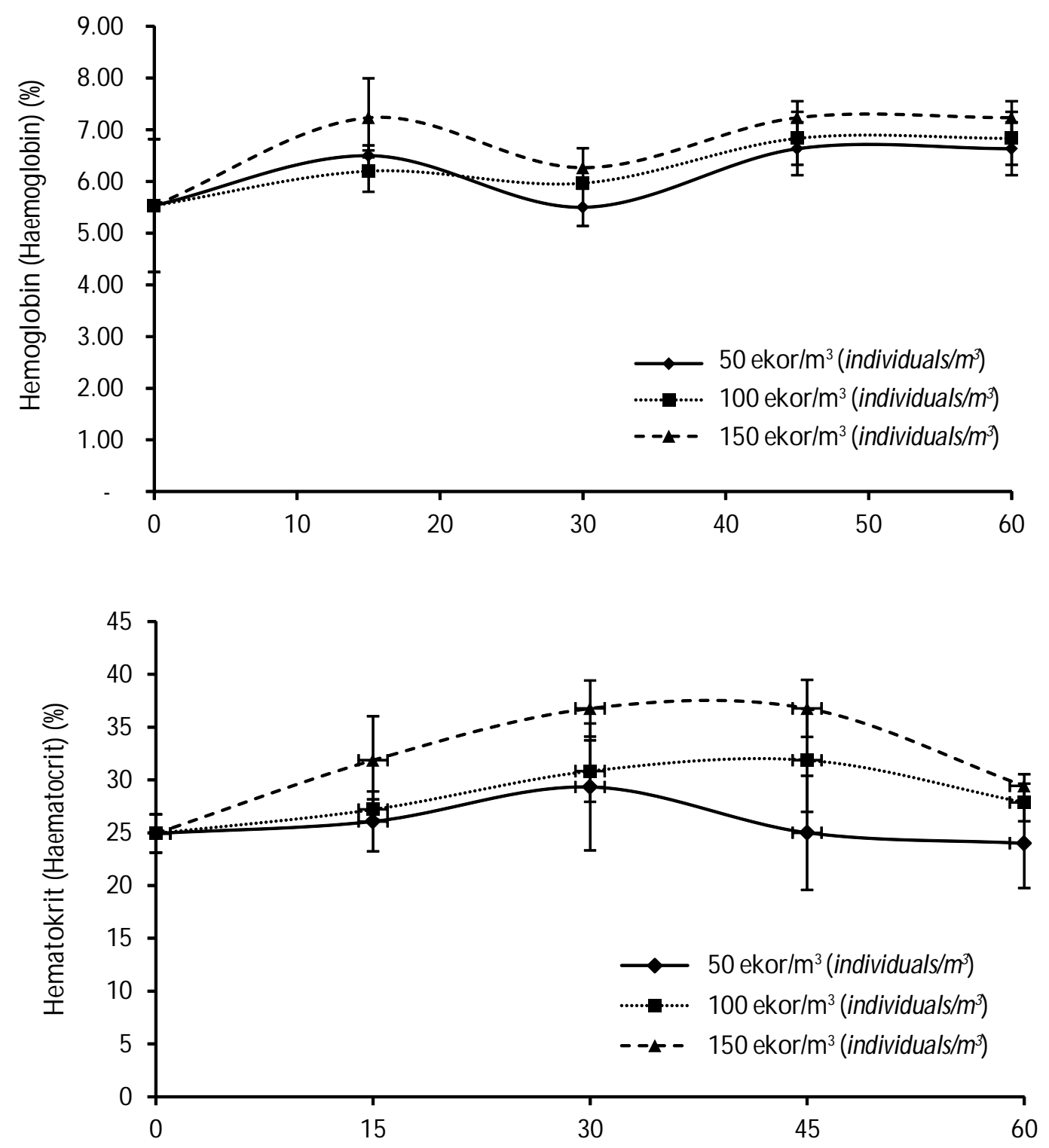

Gambar 6. Hematokrit dan hemoglobin ikan betutu pada berbagai padat tebar selama 60 hari masa.

Figure 6. Hematocrit and hemoglobin of sand goby reared for 60 days in various stocking densities.

berpengaruh terhadap performa pertumbuhan panjang mutlak dan bobot total. Padat tebar terbaik untuk mendapatkan performa pertumbuhan yang terbaik adalah 50 ekor $/ \mathrm{m}^{3}$. Kondisi ini didukung oleh hasil analisis respons fisiologi berupa gambaran darah yang paling rendah dan stabil di antara perlakuan lainnya. Kondisi ini menggambarkan ikan betutu yang dipelihara pada wadah terkontrol tidak terindikasi mengalami stres sampai akhir pemeliharaan dan hidup dalam kondisi normal.

\section{KESIMPULAN}

Padat tebar tidak berpengaruh terhadap sintasan, namun berpengaruh terhadap pertumbuhan dan gambaran darah pada pendederan benih ikan betutu. Padat tebar 50 ekor $/ \mathrm{m}^{3}$ merupakan kepadatan optimum untuk mencapai pertumbuhan terbaik benih ikan betutu, dan respons fisiologis berupa glukosa darah, total leukosit, total eritrosit, hematokrit, dan hemoglobin terbaik dibandingkan perlakuan lainnya dan biomassa tertinggi dicapai pada kepadatan 150 ekor $/ \mathrm{m}^{3}$. 


\section{UCAPAN TERIMA KASIH}

Ucapan terima kasih kami sampaikan kepada Balai Riset Perikanan Budidaya Air Tawar dan Penyuluhan Perikanan, Bogor yang telah mendanai penelitian ini melalui APBN 2016. Ucapan terima kasih kami sampaikan kepada, teknisi, dan pembudidaya ikan betutu di Parung.

\section{DAFTAR ACUAN}

Ardi, I., Setiadi, E., Kristanto, A.H., \& Widiyati, A. (2016). Salinitas optimal untuk pendederan benih ikan betutu Oxyeleotris marmorata. J. Ris. Akuakultur, 11(4), 339-347.

Arief, M., Triasih, I., \& Lokapirnasih, W.P. (2009). Pengaruh pemberian pakan alami dan pakan buatan terhadap pertumbuhan benih ikan betutu Oxyeleotris marmorata Bleeker. Jurnal IImiah Perikanan dan Kelautan, 1, 57-60.

Barreto, R.E., \& Volpato, G.L. (2006). Stress responsses of the fish nile tilapia subjected to electroshock and social stresors. Brazilian Journal of M edical and Biological Research, 30, 1605-1612.

Barton, B.A. (2002). Stress in fishes: a diversity of responses with particular reference to changes in circulating corticosteroids. Integrated Comparative Biology, 42, 517-525.

Blaxhall, P.C. (1972). The haematological assessment of the health of freshwater fish. Journal of Fish Biology, 4(4), 593-604.

Blaxhall, P.C., \& Daisley, K.W. (1973). Routine haematological methods for use with fish blood. Journal of Fish Biology, 5(6), 771-781.

Cotas, B., Arago, C., Mancera, J.M., Dinis, M.T., \& Conceicao, L.E.C. (2008). High stocking density induces crowding stress and affects amino acid metabolism in Senegalese sole Solea snegalese Kaup, 1858 juveniles. Aquacult. Res., 39, 1-9.

Courtenay, W.R., \& Williams, J.D. (2004). Snakehead Pisces, Channidae: A biological synopsis and risk assessment. Denver, Colo, USA: US Geological Survei, US Geological Survei Circular, 155 pp.

Cruz, S.A., Chao, P.L., \& Hwang, P.P. (2013). Cortisol promotes differentiation of epidermal ionocytes through Foxi3 transcription factors in zebrafish Danio rerio. Comp. Biochem. Physiol., 164, 249-257.

Darwis, M., Shaleh, S.R.M., \& Senoo, S. (2009). Daily food intake, feeding activity and growth of marble goby, Oxyeleotris marmoratus juveniles reared under different salinity levels. Aquaculture Sci., 57(2), 185-191.

Davis, A.K., Maney, D.L., \& Maerz, J.C. (2008). The use of leukocyte profiles to messure stress in vertebrates: a review for ecologist. Functional Ecology, 22(5), 760-772.

Effendie, M.I. (2002). Biologi perikanan. Yogyakarta: Yayasan Pustaka Nusatama, $163 \mathrm{hlm}$.

Hastuti, S., Supriyono, E., Mokoginta, I., \& Subandiyono. (2003). Respons glukosa darah ikan gurami Osphronemus gourami, LAC. terhadap stres perubahan suhu lingkungan. Jurnal Akuakultur Indonesia, 2(2), 73-77.

Hermawan, A.T., Iskandar, \& Subhan, U. (2012). Pengaruh padat tebar terhadap kelangsungan hidup pertumbuhan lele dumbo Clarias gariepinus Burch. di kolam Kali Menir Indramayu. Jurnal Perikanan Kelautan, 3(3), 85-93.

Ismail, K. (2010). Kiat mengatasi stres pada ikan. Jakarta: Mediatama, $68 \mathrm{hlm}$.

Iwama, G.K., Vijayan, M.M., Forsyth, R.B., \& Ackerman, P.A. (1999). Heat shock proteins and physiological stress in fish. American Zoologgist, 39, 901-909.

Joko, Muslim, \& Taqwa, F.H. (2013). Pendederan larva ikan tambakan Helostoma temmincki dengan padat tebar berbeda. Jurnal Perikanan dan Kelautan, 18(2), 59-67.

Kumai, Y., Nesan, D., Vijayan, M.M., \& Perry, S.F. (2012). Cortisol regulates $\mathrm{Na}$ + uptake in zebrafish, Danio rerio, larvae via the glucocorticoid receptor. Mol. Cel. Endocrinol., 364, 113-125.

Kusmini, I.I., Putri, F.P., \& Radona, D. (2017). Pertumbuhan dan sintasan pascalarva ikan lalawak Barbonymus balleroides Valenciennes, 1842 di akuarium dengan kepadatan berbeda. Jurnal Iktiologi Indonesia, 17(1), 21-27.

Mallya, Y.J. (2007). The effects of dissolved oxygen on fish growth in aquaculture. UNU-Fisheries Training Programme, $30 \mathrm{pp}$.

Oliveira, E.G., Pinheiro, A.B., Oliveira, V.Q., Junior, A.R., Moraes, M.G., Rocha, I.R., Sousa, R.R., \& Costa, F.H. (2012). Effect of stocking density on the performance of juvenile pirarucu Arapaima gigas in cages. Aquaculture, 370, 96-101.

Peraturan Pemerintah Republik Indonesia Nomor 82. (2001). Pengelolaan kualitas air dan pengendalian pencemaran air kelas II. hIm. 421-487.

Porchase, M.M., Luis, R., Martinez, C., Enriquez, R., $\&$ Rogelo. (2009). Cortisol and glucose: reliable indicators of fish stress. American Journal of Aquatic Science, 4, 158-178.

Prakoso, V.A., Ath-thar, M.H.F., Subagja, J., \& Kristanto, A.H. (2016). Pertumbuhan ikan uceng Nemacheilus fasciatus dengan padat tebar berbeda dalam lingkungan ex situ. J. Ris. Akuakultur, 11(4), 355-362. 
Priyadi, A., Kusrini, E., \& Megawati, T. (2010). Perlakuan berbagai jenis pakan alami untuk meningkatkan pertumbuhan dan sintasan larva ikan upside-down catfish Synodontis nigriventris. Balai Riset Budidaya Ikan Hias Depok. Prosiding Forum Inovasi Teknologi Akuakultur, hlm. 749-754.

Radona, D., Asih, S., \& Huwoyon, G.H. (2012). Optimalisasi kepadatan benih ikan mas Cyprinus carpio strain rajadanu pada pendederan di kolam air tenang. Berita Biologi, 11(2), 161-166.

Saputra, A., \& Puspaningsih, D. (2015). Peranan fotoperiod terhadap sintasan dan pertumbuhan ikan gabus Channa striata pada fase pendederan. Prosiding Forum Inovasi Teknologi Akuakultur, hlm. 745-753.

Standar Nasional Indonesia 06-6989.30-2005. Air dan air limbah-Bagian 30: Cara uji kadar amonia dengan spektrofotometer secara fenat. ICS 13.060.01.

Standar Nasional Indonesia 06-6989.9-2004 Air dan air limbah-Bagian 9: Cara uji nitrit (NO2_N) secara spektrofotometri. ICS 13.060.50.

Subagja, J., \& Radona, D. (2017). Produktivitas pascalarva ikan semah Tor douronensis Valenciennes, 1842 pada lingkungan ex situ dengan padat tebar berbeda. J. Ris. Akuakultur, 12(1), 41-48.

Sukadi, M.F., Kristanto, A.H., Nugroho, E., Komarudin, O., Widiyati, A., Gustiano, R., Djajasewaka, H., \& Kusmini, I.I. (2009). Kandidat komoditas ikan lokal air tawar potensial untuk pengembangan budidayanya di Kalimantan Selatan. Prosiding
Forum Inovasi Teknologi Akuakultur, Surabaya 23-25 Juni 2009. Pusat Riset Perikanan Budidaya, Badan Riset Kelautan dan Perikanan. Jakarta, $11 \mathrm{hlm}$.

Supriyono, E., Syahputra, R., Ghozali, M.F.R., Wahjuningrum, D., Nirmala, K., \& Kristanto, A.H. (2011). Efektivitas pemberian zeolite, arang aktif, dan minyak cengkeh terhadap hormon kortisol dan gambaran darah benih ikan patin Pangasionodon hypophthalmus pada pengangkutan dengan kepadatan tinggi. Jurnal Iktiologi Indonesia, 11(1), 67-75.

Wahyu, Supriyono, E., Nirmala, K., \& Harris, E. (2015). Pengaruh kepadatan ikan selama pengangkutan terhadap gambaran darah, pH darah, dan kelangsungan hidup benih ikan gabus Channa striata Bloch, 1793. Jurnal Iktiologi Indonesia, 15(2), 165-177.

Wedemeyer, G.A. (1996). Physiology of fish in intensive culture sytems. Springer Science \& Business Media. 232 pp.

Wedemeyer, G. (2001). Fish hatchery management. Second edition. New York: American Fisheries Society, $751 \mathrm{pp}$.

Witeska, M. (2005). Stress in fish: hematological and immunological effect of heavy metals. Electronic Journal of Ichtyology, 1(1), 35-41.

Zonneveld, N., Huisman, E.A., \& Boon, J.J. (1991). Prinsip-Prinsip Budidaya Ikan. Jakarta: Gramedia Pustaka Utama. 